\title{
Bacterial Populations in International Artisanal Kefirs
}

\author{
Abrar Sindi ${ }^{1}$, Md. Bahadur Badsha ${ }^{2,3}$ (1) and Gülhan Ünlü $1,4,5, * \mathbb{C}$ \\ 1 Department of Animal, Veterinary, and Food Sciences, University of Idaho, Moscow, ID 83844-2330, USA; \\ sind3904@vandals.uidaho.edu \\ 2 Institute for Modeling Collaboration and Innovation (IMCI), University of Idaho, Moscow, ID 83844-1122, \\ USA; mdbadsha@uidaho.edu \\ 3 Sera Prognostics, Inc., 2749 East Parleys Way, Suite 200, Salt Lake City, UT 84109, USA \\ 4 School of Food Science, Washington State University, P.O. Box 646376, Pullman, WA 99164-6376, USA \\ 5 Department of Biological Engineering, University of Idaho, Moscow, ID 83844-0904, USA \\ * Correspondence: gulhan@uidaho.edu; Tel.: +1-208-885-7771; Fax: +1-208-885-2567
}

Received: 18 July 2020; Accepted: 27 August 2020; Published: 29 August 2020

\begin{abstract}
Artisanal kefir is a traditional fermented dairy product made using kefir grains. Kefir has documented natural antimicrobial activity and health benefits. A typical kefir microbial community includes lactic acid bacteria (LAB), acetic acid bacteria, and yeast among other species in a symbiotic matrix. In the presented work, the $16 \mathrm{~S}$ rRNA gene sequencing was used to reveal bacterial populations and elucidate the diversity and abundance of LAB species in international artisanal kefirs from Fusion Tea, Britain, the Caucuses region, Ireland, Lithuania, and South Korea. Bacterial species found in high abundance in most artisanal kefirs included Lactobacillus kefiranofaciens, Lentilactobacillus kefiri, Lactobacillus ultunensis, Lactobacillus apis, Lactobacillus gigeriorum, Gluconobacter morbifer, Acetobacter orleanensis, Acetobacter pasteurianus, Acidocella aluminiidurans, and Lactobacillus helveticus. Some of these bacterial species are $\mathrm{LAB}$ that have been reported for their bacteriocin production capabilities and/or health promoting properties.
\end{abstract}

Keywords: fermented food; fermented beverage; dairy fermentation; artisanal kefir; artisanal kefir grain; lactic acid bacteria (LAB), acetic acid bacteria; $16 \mathrm{~S}$ rRNA gene sequencing; microbial population; microbiome; probiotic; health benefits; bacteriocin; safe food

\section{Introduction}

Artisanal kefir is an ancient fermented beverage obtained via fermentation of milk by kefir grains [1]. Kefir grains are a combination of yeast, bacteria, and bacterial polysaccharides [2]. Up to 50 different bacterial and yeast species have been identified in artisanal kefirs [1,3,4]. Numerous combinations of these microorganisms at the species level lead to artisanal kefirs with unique characteristics. It is important to determine the specific microbial compositions of artisanal kefirs and their grains from different origins [5] to obtain a better understanding of kefir as a functional dairy product. Early attempts to isolate kefir-associated microorganisms were obstructed by these microorganisms' fastidious nature. The lactic acid bacteria (LAB) found in kefir require specific nutrients and conditions for growth, so select LAB in kefir may have been undetected via culture-dependent methods [6]. Culture-independent methods are commonly used to identify microbial diversity in fermented foods and beverages. Among these methods, the 16S rRNA gene sequencing has been suggested as a suitable method for identification of bacteria at the species level [7].

As previously mentioned, a typical kefir microbial community includes LAB, acetic acid bacteria, and yeast among other species in a symbiotic matrix [8]. The 16S rRNA gene sequencing has been successfully used to identify bacterial species in kefir $[9,10]$. For example, Gulitz et al. identified Lactobacillus nagelii (Liquorilactobacillus nagelii), Lactobacillus hordei 
(Liquorilactobacillus hordei), Bifidobacterium psychraerophilum, Lactobacillus hilgardii (Lentilactobacillus hilgardii), Lactobacillus satsumensis (Liquorilactobacillus satsumensis), Acetobacter orientalis, Clostridium tyrobutyricum, and Leuconostoc citreum from kefir originated from Germany using the 16S rRNA gene sequencing of the V1 to V4 hypervariable regions [10]. Another study identified Lactobacillus kefiranofaciens, Lactobacillus acidophilus, and Lactobacillus sunkii (Lentilactobacillus sunkii) with abundance of $77-78 \%, 10-11 \%$, and $2-4 \%$, respectively, in two Turkish kefir grains using whole genome and $16 \mathrm{~S}$ rRNA shotgun sequencing [2].

$\mathrm{LAB}$ are known to produce one or more of the following products with antimicrobial properties: organic acids, free fatty acids, diacetyl, hydrogen peroxide, and bacteriocins. Bacteriocins are ribosomally synthesized proteins or peptides that are secreted by bacteria and inhibit closely related Gram-positive and some Gram-negative bacteria using various mechanisms of action [11]. Kefir contains LAB which are known to produce bacteriocins. For example, Lacticin 3147, a bacteriocin produced by Lactococcus lactis DPC3147 isolated from Brazilian kefir grains, inhibited the growth of Escherichia coli, Listeria monocytogenes, Salmonella typhimurium, and Salmonella enteritidis [12].

FAO/WHO (Food and Agriculture Organization and the World Health Organization) define probiotics as "live microorganisms which when administered in adequate amounts confer a health benefit to the host" [13]. Recently, The International Scientific Association for Probiotics and Prebiotics recommended that "the term probiotic be used only on products that deliver live microorganisms with a suitable viable count of well-defined strains with a reasonable expectation of delivering benefits for the wellbeing of the host" [14]. Kefir, reported as a natural probiotic beverage by some researchers [1], contains LAB species with documented beneficial properties. For example, L. kefiranofaciens XL10, which is a homofermentative LAB that produces lactic acid as the main product, was reported to have probiotic properties in both in vitro and in vivo studies $[15,16]$. Lactobacillus kefiri (Lentilactobacillus kefiri) is a heterofermentative LAB that produces lactic acid, acetic acid, ethanol, and carbon dioxide, and was reported, in both in vivo and in vitro studies, to have probiotic properties such as adherence to mucus extracted from the small intestine and colon, strong cholesterol assimilation abilities, and lowering the secretion of IL-8 caused by Salmonella enterica infection $[17,18]$.

In our recently published work [19], the antimicrobial activities of artisanal kefir products from Fusion Tea, Britain, the Caucuses region, Ireland, Lithuania, and South Korea were investigated against select foodborne pathogens. It was confirmed that bacteriocin production is the main reason for these kefirs' antimicrobial activity [19]. In the presented work, the 16S rRNA gene sequencing was used to reveal bacterial populations and elucidate the diversity and abundance of LAB species in these international artisanal kefirs. Several LAB species identified in the presented work have been reported by other researchers to have bacteriocin production capabilities and/or health promoting properties. Based on our findings, bacteriocin-producing and/or potentially beneficial LAB are being isolated from select artisanal kefirs and being characterized in our laboratory.

\section{Materials and Methods}

\subsection{Genetic Approaches for Identification of Bacteria in Kefir}

\subsubsection{Kefir Preparation}

Six artisanal kefir grains originating from South Korea (K; [20]), Ireland (I; Etsy Inc.), Lithuania (L; Etsy Inc.), Britain (B; Etsy Inc.), the Caucuses (C; Etsy Inc.), and a compilation of world-sourced grains blended (A; Fusion Tea, Amazon) were used in this study. Kefir grains were inoculated (10\% (w/v)) into whole pasteurized milk and incubated at $22-24{ }^{\circ} \mathrm{C}$ for $24 \mathrm{~h}$. At the end of the fermentation process ( $\mathrm{pH} 3.9-4.1$ ), clean plastic strainers with 1-mm pore size was used to separate kefir grains from kefir products. Designated plastic strainers were used for each kefir product/grains to avoid cross contamination. Kefir products were centrifuged (Eppendorf Microcentrifuge 5415D, Hauppauge, NY, USA) at 16,000 $\mathrm{g}$ for $10 \mathrm{~min}$ at room temperature to remove the lipid layer. Kefir grains separated were washed three times with sterilized DI water. Kefir grains were mixed with sterile DI water (3 mL), 
homogenized using Stomacher 400 (Seward Limited, Worthing, West Sussex, UK) for 60-120 s at high speed, and then centrifuged at $16,000 \mathrm{~g}$ for $10 \mathrm{~min}$ at room temperature to remove the lipid layer. The resulting pellets were used for DNA extractions.

\subsubsection{DNA Extraction}

The E.Z.N.A Universal Pathogen Kit (Omega Biotech, Norcross, GA, USA) was used for DNA extraction from all international artisanal kefirs and their grains. The kit's user guide was followed with two additional washing steps with the DNA washing buffers included in the kit. The concentration of DNA preparations was determined by ultraviolet spectrophotometry (Spectra MAX 190). Absorbance 260/280 values between 1.8 and 2.0 were considered acceptable. The quality of DNA preparations was determined by running DNA samples on $1.2 \%(\mathrm{w} / \mathrm{v})$ agarose gels with TAE (1X) buffer and using PowerPac 200 submerged horizontal gel electrophoresis systems from Bio-Rad (Hercules, CA, USA). Two DNA samples, one representing a given kefir product and another representing the kefir grains in that product, were sent out to Omega Bioservices (Norcross, GA, USA) for the 16S rRNA gene sequencing. With two DNA samples representing a given artisanal kefir, a total of 12 DNA samples representing six international artisanal kefirs were sequenced by Omega Bioservices.

Commercial kefirs, made with known cultures indicated on their labels, were purchased from local (Moscow, ID, USA) grocery stores and used as controls: Lifeway (plain), The Greek Gods (plain), Wallaby (organic plain), and Maple Hill (organic plain). DNA from the commercial kefir samples was extracted by Omega Bioservices using their E.Z.N.A Universal Pathogen Kit.

\subsubsection{The16S rRNA Gene Sequencing}

Illumina MiSeq Sequencing was used for the 16 S rRNA gene sequencing ( $\approx 200 \mathrm{~K}$ reads per sample) by Omega Bioservices. Both the V1-V3 and the V3-V4 primer sets were used for PCR amplification by Omega Bioservices. The V1 and V2 regions have been historically used for identification of LAB [21]. All variable regions in the $16 \mathrm{~S}$ rRNA gene have been reported to be effective in identifying bacterial communities in kefir through the 16S rRNA gene sequencing [22]. Library preparation type was KAPA HiFi PCR as per Omega Bioservices. Data was delivered via Illumina BaseSpace web site.

\subsection{The $16 S$ rRNA Gene Sequencing Analyses}

The 16S rRNA gene sequencing reads were obtained from Omega Bioservices for the V1-V3 and the V3-V4 regions. The total number of reads (often referred to as read depth) were converted to relative abundance and rounded to $0.1 \%$. The percent relative abundance was calculated by dividing the number of reads for each phylum, genera, or species with the total number of reads for each kefir and multiplying the outcome by 100. Pie charts were created for the relative abundances of bacterial phyla in kefir products and their grains based on the V1-V3 and V3-V4 regions of the 16S rRNA genes. Stacked bar charts were created for the average abundance of the 21 most abundant bacterial genera, based on the V1-V3 and V3-V4 regions of the 16S rRNA genes, in kefir products and their grains. Additional stacked bar charts were created for the average relative abundance of the 10 most abundant bacterial species, based on the maximum percentage between the V1-V3 and the V3-V4 regions of the $16 \mathrm{~S}$ rRNA genes, and scaling (0-100) species contribution. Stacked bar charts were also created for the percent species contribution of LAB found in kefir samples and known to produce bacteriocins, based on the maximum percentage between the V1-V3 and the V3-V4 regions of the $16 \mathrm{~S}$ rRNA genes, and scaling (0-40) species contribution. Canonical correlations were performed using the aggregated lists of taxa to examine relationships among kefir products and their grains. Correlation plots were used to understand whether and how strongly kefir products and their grains are related. The Pearson's correlation coefficient $(r)$ provides information about the strength and direction of a relationship between a given kefir product and its grains. The regression line describes how kefir products change as kefir grains change. Heatmaps were created using Pearson correlations among the kefir products and their grains. The results of hierarchical clustering (HC) using complete linkage 
distance method represented by a dendrogram was included to show taxonomic relationships among international artisanal kefirs. The Pearson's correlation coefficients, regression lines, and dendrogram were generated by R-3.5.1 programming (R Studio Inc., Boston, MA, USA).

\section{Results}

\subsection{Genetic Approaches for Identification of Bacteria in Kefir Samples}

\subsubsection{Bacterial Phyla and Genera Present in Artisanal Kefirs and Their Grains}

Based on the 16S rRNA sequencing data generated in this work, a diverse group of bacteria were determined to be present in artisanal kefir products and their grains from different regions of the world. Specifically, relative abundances of bacterial phyla and bacterial genera based on the V1-V3 and the V3-V4 regions of the 16S rRNA genes were determined for the kefir product from Lithuania (LP), kefir grains from Lithuania (LG), kefir product from South Korea (KP), kefir grains from South Korea $(\mathrm{KG})$, kefir product from Ireland (IP), kefir grains from Ireland (IG), kefir product from the Caucuses region $(C P)$, kefir grains from the Caucuses region $(C G)$, kefir product from Britain (BP), kefir grains from Britain (BG), kefir product from Fusion Tea (AP, Amazon), and kefir grains from Fusion Tea (AG, Amazon) (Figure 1). The Firmicutes phylum was the most abundant in all artisanal kefir products, followed by the phyla Proteobacteria, Actinobacteria, Verrucomicrobia, Planctomycetes, and Nitrospirae (Figure 1). The phylum Firmicutes was the most abundant phylum in kefir grains, especially for CG, with 97.9\% (based on V1-V3) and 97.7\% (based on V3-V4) (Figure 1), followed by BG, LG, AG, KG, and IG for the V1-V3 regions (Figure 1). Based on the V3-V4 regions, Firmicutes was the most abundant phylum in CG followed by LG, BG, AG, KG, and IG (Figure 1). The following genera were identified as the major genera in artisanal kefirs: Lactobacillus, Lentilactobacillus, Lacticaseibacillus, Acetobacter, Swaminathania, Gluconobacter, Streptococcus, Pediococcus, Pseudomonas, Acidocella, Cohnella, Peptoniphilus, Saccharopolyspora, Thermodesulfovibrio, Singulisphaera, Chthoniobacter, Paenibacillus, Knoellia, Leuconostoc, Bifidobacterium, and Lactococcus (Figure 1).

The 16S rRNA gene sequencing targeting the V1-V3 and the V3-V4 regions resulted in various relative abundance percentages for the phylum and genus level designations in all artisanal kefirs (Figure 1). For example, LP has 67\% Firmicutes based on the V1-V3 region, while it has 64.6\% Firmicutes based on the V3-V4 region. The IP has $65.6 \%$ and $69.7 \%$ Firmicutes based on the V1-V3 and the V3-V4 regions, respectively. The AP has the highest relative abundance for Lactobacillus species, from $75 \%$ (based on V1-V3) to $75.5 \%$ (based on V3-V4) while LP has the lowest abundance for Lactobacillus species from $61.6 \%$ (based on V3-V4) to $64.2 \%$ (based on V1-V3). The genus Lentilactobacillus was found to be in the highest abundance in IG, from 7.7\% (based on V1-V3) to 7.4\% (based on V3-V3), when compared to all other kefir grains and products. It appears that the combination of both the V1-V3 and V3-V4 regions to identify bacteria at the phylum and genus levels in kefir products and their grains worked well. As an exception, the V3-V4 region identified the genus Swaminathania in all kefir products and in all kefir grains (Figure 1B), while it was not identified by the V1-V3 region (Figure 1A).

Commercial kefirs are defined, prepared using a starter culture of LAB and yeast species as indicated on the packaging. Therefore, the $16 \mathrm{~S}$ rRNA gene sequencing was performed on commercial kefirs as controls to test the accuracy of the identification. Commercial kefirs used in the study were determined to have the exact probiotic bacteria, both at the genus and species level as listed on their labels. (Figure S1). 


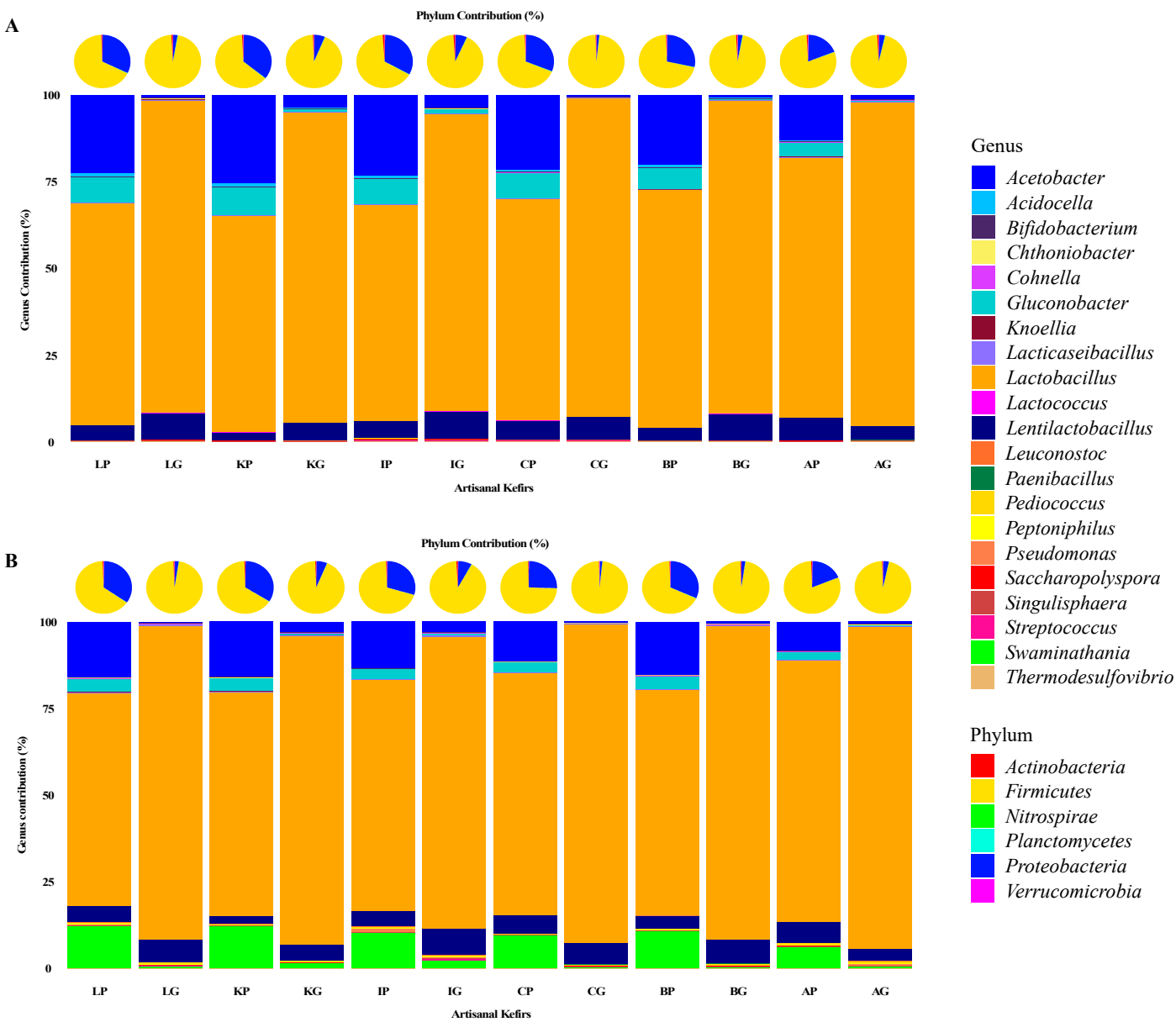

Figure 1. Relative abundances of bacterial phyla (pie charts) and an aggregation of the 21 most abundant bacterial genera (column charts) for the V1-V3 (A) and V3-V4 (B) regions of the 16S rRNA genes. Kefir product from Lithuania (LP), kefir grains from Lithuania (LG), kefir product from South Korea (KP), kefir grains from South Korea (KG), kefir product from Ireland (IP), kefir grains from Ireland (IG), kefir product from the Caucuses region (CP), kefir grains from the Caucuses region (CG), kefir product from Britain (BP), kefir grains from Britain (BG), kefir product from Fusion Tea (AP, Amazon), kefir grains from Fusion Tea (AG, Amazon).

\subsubsection{Bacterial Species Present in Artisanal Kefirs and Their Grains}

The 10 most abundant bacterial species found in artisanal kefirs included L. kefiranofaciens, Lent. kefiri, Lactobacillus ultunensis, Lactobacillus apis, Lactobacillus gigeriorum, Gluconobacter morbifer, Acetobacter orleanensis, Acetobacter pasteurianus, Acidocella aluminiidurans, and Lactobacillus helveticus (Figure 2). L. kefiranofaciens was determined to be the most abundant bacterium in all artisanal kefirs with relative abundance between $48.22 \%$ and $93.76 \%$ (Figure 2). The relative abundance for Lent. kefiri varied between $2.94 \%(\mathrm{KP})$ and $7.3 \%$ (AP) among kefir products and between $3.7 \%(\mathrm{AG})$ and $7.86 \%$ (IG) among kefir grains (Figure 2). L. ultunensis was found to be more abundant in KP and KG when compared to all other artisanal kefirs and their grains. A. pasteurianus was more abundant (17.1\%) in KP while G. morbifer was more abundant (5.8\%) in LP when compared to their relative abundance in all other artisanal kefirs.

Differences exist in artisanal kefirs regarding microorganisms present in kefir products versus their grains. For example, L. kefiranofaciens exhibits a higher relative abundance in all kefir grains when compared to their corresponding products (Figure 2). Similarly, Lent. kefiri exhibits a higher relative abundance in kefir grains B, I, K, and L when compared to their corresponding products (Figure 2). 
On the other hand, Lent. kefiri exhibits a lower relative abundance (3\%) in AG when compared to that $(6 \%)$ of in AP (Figure 2).

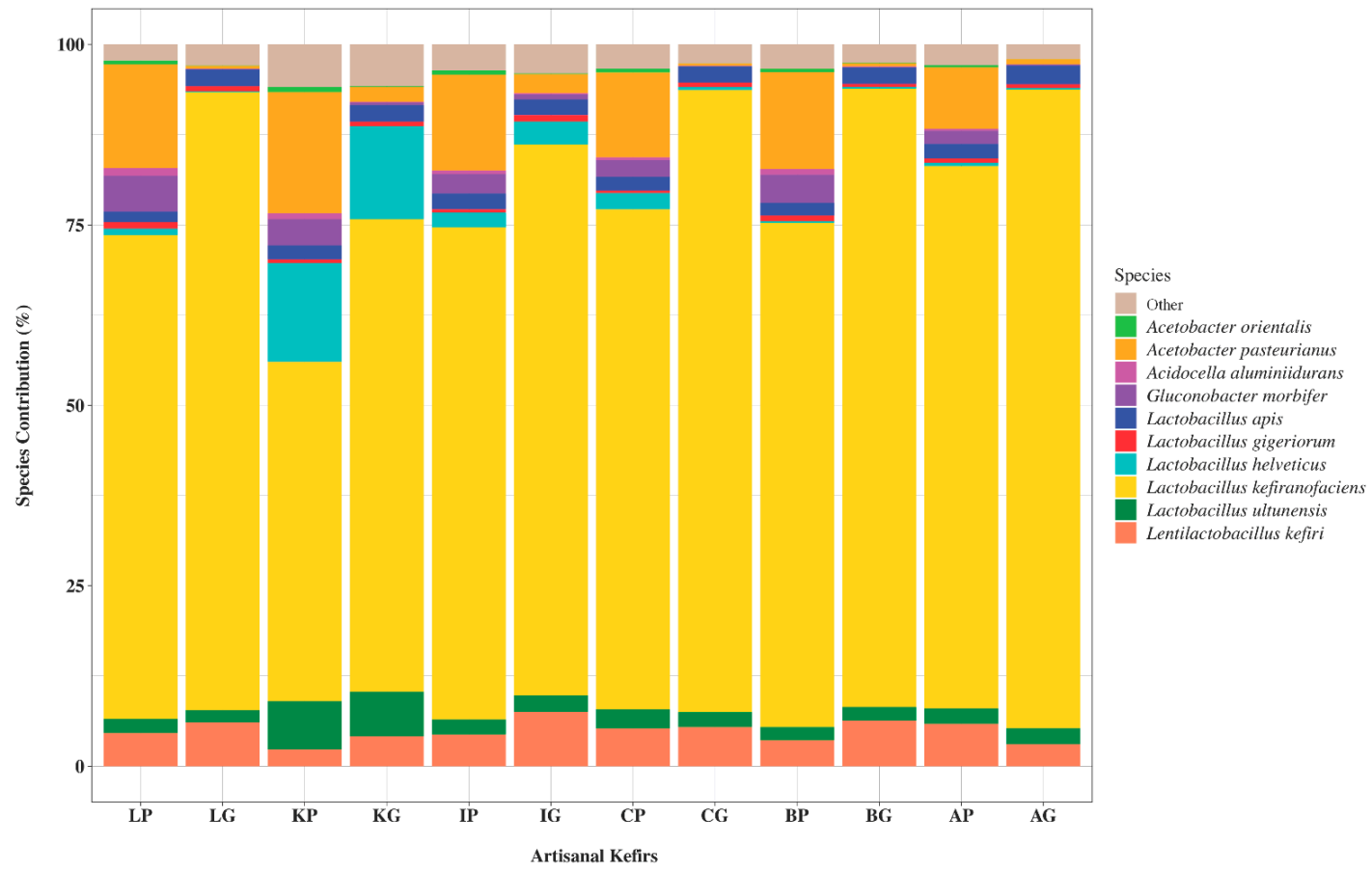

Figure 2. An aggregation of the 10 most abundant bacterial species, using the calculated relative abundance and scaling (0-100) species contribution. Kefir product from Lithuania (LP), kefir grains from Lithuania (LG), kefir product from South Korea (KP), kefir grains from South Korea (KG), kefir product from Ireland (IP), kefir grains from Ireland (IG), kefir product from the Caucuses region $(\mathrm{CP})$, kefir grains from the Caucuses region (CG), kefir product from Britain (BP), kefir grains from Britain (BG), kefir product from Fusion Tea (AP, Amazon), kefir grains from Fusion Tea (AG, Amazon).

\subsubsection{Bacteriocinogenic and Beneficial Bacteria in Artisanal Kefirs}

Several LAB species recognized as bacteriocin producers in the current literature were identified in all artisanal kefirs subjected to this work, albeit in various relative abundance (Figure 3). The following bacteriocinogenic species were found in artisanal kefirs: Lent. kefiri, L. helveticus, Lactobacillus delbrueckii, Lacticaseibacillus paracasei (Lactobacillus paracasei), Lacticaseibacillus casei (Lactobacillus casei), Lacticaseibacillus rhamnosus (Lactobacillus rhamnosus), L. apis, Lactobacillus crispatus, Lactobacillus acidophilus, Streptococcus thermophilus, Leuconostoc mesenteroides, and Lactococcus lactis (Figure 3). All artisanal kefirs, except kefir $\mathrm{K}$, were determined to contain Lent. kefiri as the most abundant LAB with known bacteriocin production capability. Lent. kefiri was the third most abundant LAB with known bacteriocin production in Kefir K (Figure 3).

Kefir $\mathrm{K}$ was a stand-alone kefir product with respect to the ranking of species with known bacteriocin production: L. helveticus, L. crispatus, Lent. kefiri, L. apis, and L. acidophilus. The most abundant LAB with known bacteriocin production capability was identified to be L. helveticus in KP with relative abundance of $21.8 \%$ and in KG with relative abundance of $17.8 \%$ (Figure 3). L. helveticus was found in other artisanal kefir products with relative abundance between $0.26 \%$ (BP) and $4.11 \%$ (CP) and in artisanal kefir grains with relative abundance between $0.13 \%$ (LG) and 3.34\% (IG).

Lactobacillus crispatus, another Lactobacillus species with known bacteriocin production, followed L. helveticus in KP and KG with relative abundance of 3.44\% and 2.93\%, respectively (Figure 3). The relative abundance for $L$. crispatus in other artisanal kefir products and kefir grains varied between $0.07 \%(\mathrm{BP})$ and $0.6 \%(\mathrm{CP})$ and between $0.045 \%(\mathrm{BG})$ and $0.51 \%(\mathrm{IG})$, respectively. 


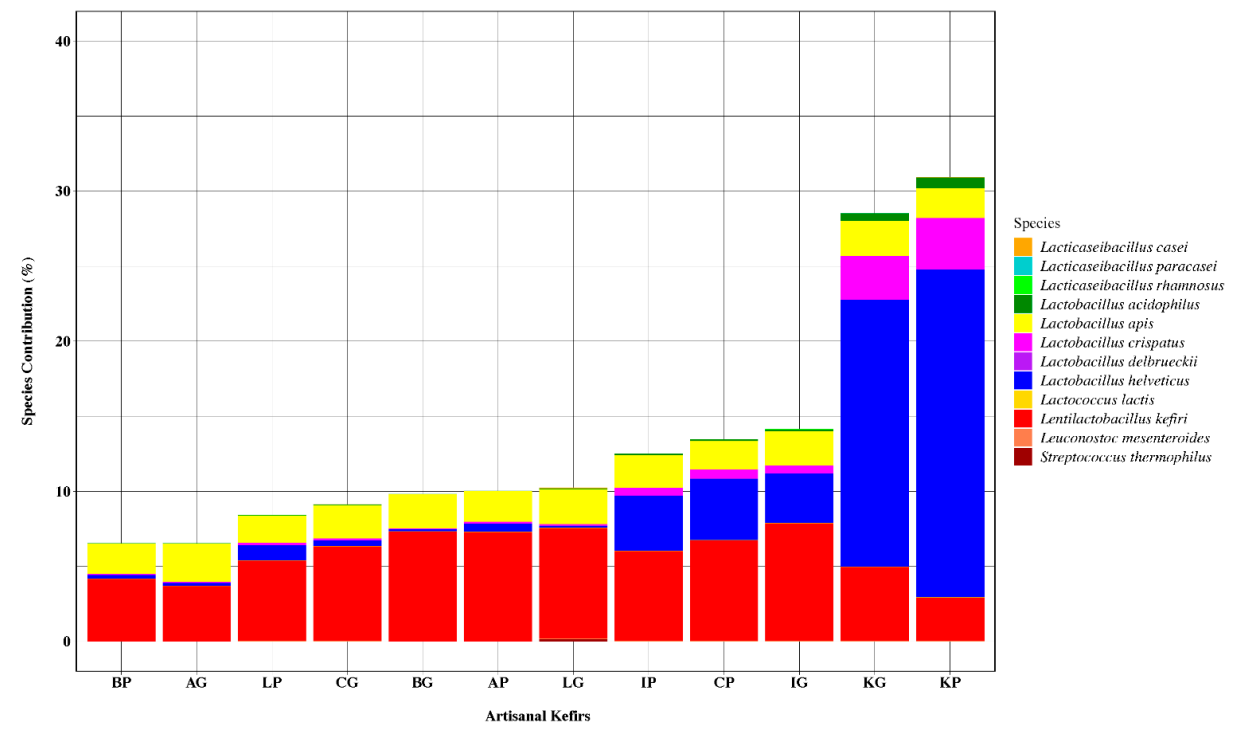

Figure 3. The $16 \mathrm{~S}$ rRNA gene sequencing results showing percent species contribution of lactic acid bacteria (LAB). The IP, and IG share the same ranking with CP: L. apis, L. helveticus, L. acidophilus, and L. crispatus. The CG shares with IP, IG, and CP the same ranking for L. crispatus and L. acidophilus only. The LG has the highest relative abundance for $S$. thermophilus and the lowest relative abundance for L. helveticus when compared to LP as well as other artisanal kefirs.

Lactobacillus apis, a lesser known Lactobacillus species with reported bacteriocin production capability, was determined to be present in all artisanal kefir products and their grains. The relative abundance of L. apis was in the range of $1.79 \%$ (LP) to $2.17 \%$ (IP) in kefir products and $2.21 \%$ (CG) to $2.54 \%$ (AG) in kefir grains (Figure 3). L. apis was determined to have the second highest and the third highest relative abundance among other bacteriocin producing LAB in kefir products $\mathrm{A}, \mathrm{B}, \mathrm{I}$, and $\mathrm{L}$ and kefir product $C$, respectively (Figure 3 ). The organism had the second highest abundance ranking among other bacteriocin producing LAB in kefir grains $\mathrm{A}, \mathrm{B}, \mathrm{C}, \mathrm{L}$, while the ranking was the third highest abundance in kefir grain I and the fourth highest abundance in kefir K (Figure 3).

Lactobacillus acidophilus, an organism with reported bacteriocin production capability, ranked fifth most abundant bacteriocinogenic LAB species in all artisanal kefir products. L. acidophilus was present in $\mathrm{KP}$ with relative abundance of $0.7 \%$ and in $\mathrm{KG}$ with relative abundance of $0.5 \%$ (Figure 3). All other artisanal kefirs (A, B, C, I, and L), both products and their grains, were determined to contain much less L. acidophilus with relative abundance of $0.01 \%-0.1 \%$ (Figure 3).

Some LAB species with known bacteriocin production capability were absent in select kefir products plus their grains (Figure 3): S. thermophilus in kefir A; L. delbrueckii in kefir A; Lacti. paracasei in kefirs A and B; Lacti. casei in kefirs A, B, C, I, and $\mathrm{K}$; Lacti. rhamnosus in kefir K; Lac. lactis in kefirs B, C, and K; and Leu. mesenteroides in kefirs A, B, I, and L. Lacti. casei was determined to be present, albeit at a low relative abundance, in kefir $\mathrm{L}$ grains only (Figure 3).

\subsubsection{Correlation of Artisanal Kefir Products to Their Grains and Taxonomic Relationships Among} International Artisanal Kefirs

Kefir grains showed a high correlation to their products in their species content (Figure 4A-C). Kefir A presented the highest correlation between its grains and the product $(r=0.994)$, followed by kefirs I, C, B, and L with the following $r$ values, respectively: $r=0.986,0.986,0.981$, and 0.976 . The lowest correlation was observed in kefir K $(r=0.948)$, (Figure 4B). The heatmap (Figure 4C) created confirmed that KG and KP had the lowest correlation with each other and the lowest correlation with all other kefirs (Figure 4C). The AP, on the other hand, appeared to have the highest correlation with all kefir grains $(r=1)$ except for KG. The AG was not highly correlated with other kefir products (Figure 4C). 

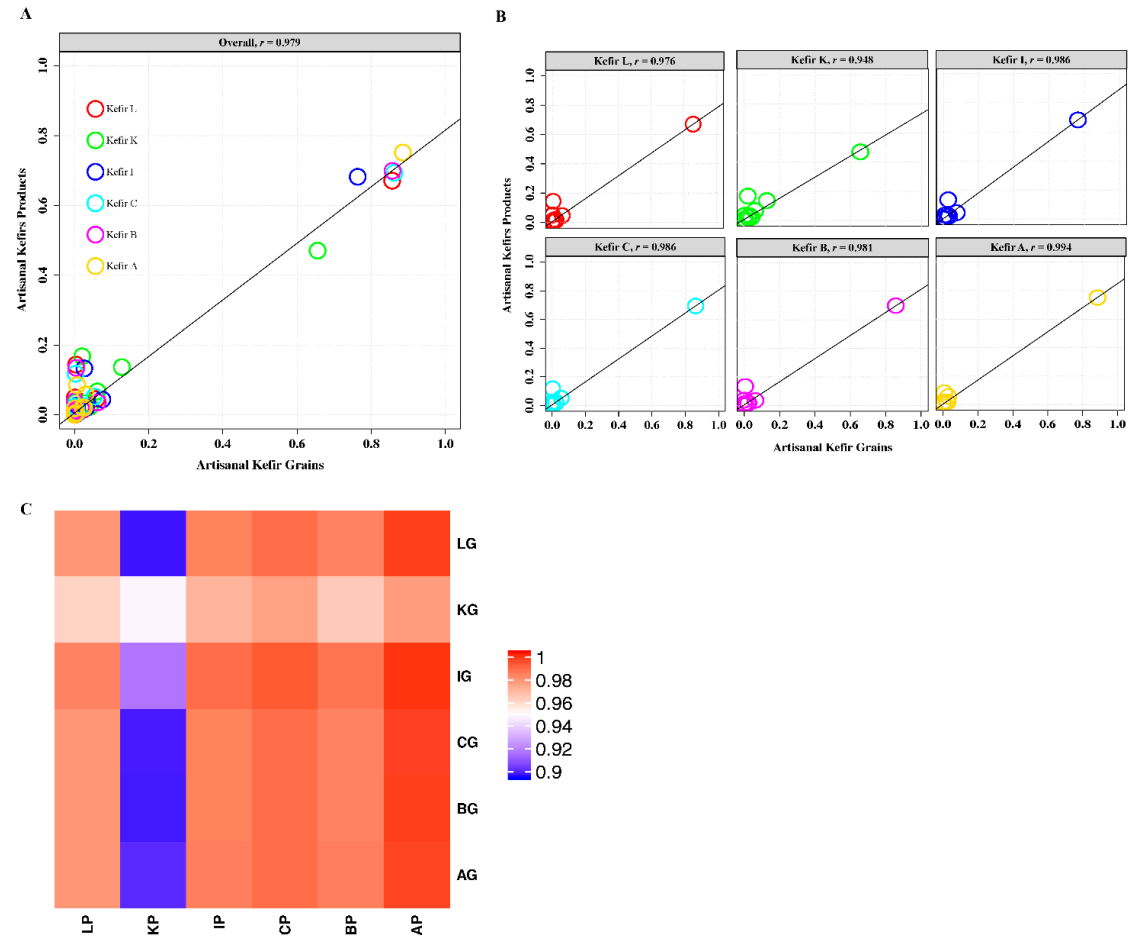

Figure 4. (A) Canonical correlation plot with a regression line between all kefir grains (x-axis for each plot) from Lithuania (LG) and South Korea (KG), Ireland (IG), the Caucuses region (CG), Britain (BG), and Fusion Tea (AG, Amazon), and all kefir products (y-axis for each plot) from Lithuania (LP) and South Korea (KP), Ireland (IP), the Caucuses region (CP), Britain (BP), and Fusion Tea (AP, Amazon) for species level. (B) Correlation plots with a regression line between each kefir grains and their products. The $r$ indicates the Pearson's correlation coefficient for each plot. (C) Heatmap showing Pearson correlation between each kefir grains and their products.

Hierarchical Clustering (HC) dendrogram (Figure 5) shows taxonomic relationships among international artisanal kefirs. KP appears to be a stand-alone kefir product with respect to species- level taxonomy. KP has its own highest cluster, while AP is the most related kefir to KP when compared to all other kefir products. In addition, IP and CP are related with respect to species-level taxonomy similar to LP and BP which are also related to each other (Figure 5).

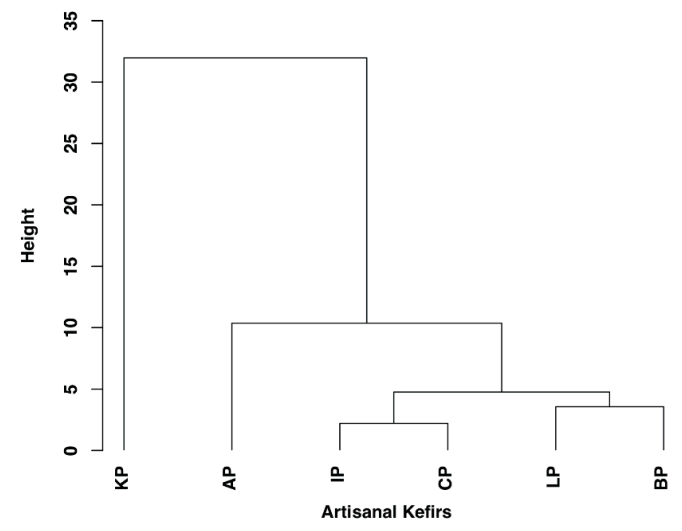

Figure 5. The hierarchical clustering (HC) based dendrogram showing species level taxonomy relatedness for all kefir products (X-axis) from Lithuania (LP) and South Korea (KP), Ireland (IP), the Caucuses region (CP), Britain (BP), and Fusion Tea (AP, Amazon). The complete linkage method used for computing distance between clusters to determine similar clusters. 


\section{Discussion}

In the presented work, the $16 \mathrm{~S}$ rRNA gene sequencing was successfully applied to six international artisanal kefirs and revealed microbial populations at the phyla, genera, and species levels in international artisanal kefirs. A total of six phyla were identified, Firmicutes Proteobacteria, Actinobacteria, Verrucomicrobia, Planctomycetes, and Nitrospirae, in artisanal kefirs studied. To our knowledge, the presence of a combination of six phyla has not been reported for any artisanal kefir. This could be due to the complexity of the artisanal kefirs examined in our work and/or the effectiveness of the 16S rRNA gene sequencing and the sequence analyses. The phylum Firmicutes was the most abundant phylum among all other phyla in kefir grains and their products, which is a commonly found phylum in artisanal kefir. Lactobacillus was the most abundant genus with the highest relative abundance in AG and the lowest relative abundance in IP. This aligns well with relative abundance of lactobacilli in artisanal kefirs described in the literature. The genus Lactobacillus has been recently reclassified into 25 new genera including Lactobacillus, Lentilactobacillus, and Lacticaseibacillus [23]. This reclassification was fully considered in our work.

Our goal was to utilize multiple variable regions of the 16S rRNA gene to successfully identify all genera and species present in international artisanal kefirs. One interesting outcome of our study was the identification of the genus Swaminathania through the use of the V3-V4 region of the 16S rRNA gene but not through the use of the V1-V3 region. Since the 16S rRNA gene sequencing of four commercial kefirs, used as controls to test the accuracy of the identification, determined the exact probiotic bacteria listed on their labels at the species level, we are confident with the results of the $16 \mathrm{~S}$ rRNA gene sequencing. The interesting outcome can be attributed to the fact that different variable regions in the 16S rRNA gene can be less or more suitable to identify bacteria at the genus or species level. Perhaps the V1-V3 region is less suitable for identification of the genus Swaminathania than the V3-V4 region.

A study by Marsh et al. for kefirs sourced from the United Kingdom, Canada, and the United States reported that the 16S rRNA reads for the V4-V5 region identified three bacterial phyla: Actinobacteria, Firmicutes, and Proteobacteria [24]. Both Proteobacteria and Firmicutes were verified to be the most abundant phyla. The Proteobacteria phylum was greater in abundance, in general, in the grains than the products for all kefirs studied. The phylum Firmicutes was in higher abundance in the product than in the grains. The abundance of Actinobacteria was low, in general, in both grains and products. Marsh et al. found that the most dominant genus was Zymomonas with a relative abundance of $87-49 \%$ followed by Lactobacillus, ranging in relative abundance from $38.8 \%$ to $12 \%$ [24]. Differences observed between our work and that of Marsh et al. can be attributed to differences among the kefirs used and the regions that were targeted in the $16 \mathrm{~S}$ rRNA sequencing.

Lentilactobacillus kefiranofaciens was the most abundant lactobacilli in all artisanal kefirs. Our findings align with that of Wang et al., who reported L. kefiranofaciens as the sole dominant and stable species in Tibetan kefir [25]. L. kefiranofaciens has been reported to have probiotic properties and health benefits [26,27]. A study with both in vivo and in vitro components suggested L. kefiranofaciens M1 to be applied in fermented dairy products as an alternative therapy for intestinal disorders [26]. An increase in the production of regulatory T-cell cytokines was observed when Lb. kefiranofaciens M1 was cocultured with spleen cells [27].

Other highly abundant bacterial species identified in artisanal kefirs in the presented work included the following organisms: Lenti. kefiri, L. ultunensis, L. apis, L. gigeriorum, G. morbifer, A. orleanensis, A. pasteurianus, Acid. aluminiidurans, and L. helveticus. Out of these, L. ultunensis and L. apis were reported to be present in kefir grains from different regions of Turkey [28]. Based on our knowledge, L. gigeriorum has not been reported in kefir until the presented work, however, the organism has been reported to be closely related to L. acidophilus [29]. In addition, our work is the first study reporting Acid. aluminiidurans occurrence in kefir. Acid. aluminiidurans is an aluminum-, acid-, and sulfate-tolerant bacterium, which was originally isolated from a waterweed in Vietnam [30]. 
Lentilactobacillus kefiri was found in higher relative abundance in kefir grains $\mathrm{B}, \mathrm{I}, \mathrm{K}$, and L when compared to their corresponding products. Perhaps Lenti. kefir is imbedded in the outer layers of the kefir A grains and immigrate, during kefir fermentation, more into the kefir product than in kefirs B, I, K, and L. A study by Korsak et al. evaluated the microbiota of kefir samples from Belgium using $16 S$ pyrosequencing revealed the presence of L. kefiranofaciens, Lactococcus lactis ssp. cremoris, Gluconobacter frateurii, Lenti. kefiri, A. orientalis, Leu. mesenteroides, and Acetobacter lovaniensis [31]. In that study, some samples showed L. kefiranofaciens to be the most abundant—similar to our work-while other samples showed Lac. lactis as the most abundant, constituting $\approx 80 \%$ of the bacterial population. Korsak et al. samples [31] did not report the occurrence of L. ultunensis, L. apis, L. gigeriorum, G. morbifer, A. orleanensis, A. pasteurianus, Acid. aluminiidurans, and L. helveticus, which are being reported in the presented study. As expected, similarities and differences exist among international artisanal kefirs regarding their bacterial populations at the species level.

Acetic acid bacteria have been reported to contribute to exopolysaccharide formation and increase in kefir grain biomass, without negatively affecting the sensory properties and other microflora of kefir [32]. Acetobacter fabarum, A. lovaniensis, and A. orientalis were identified in kefir originated from Italy [33]. A. orleanensis, A. orientalis, Acetobacter malorum, and A. pasteurianus were found in all artisanal kefirs in the presented work. Therefore, it appears that different acetic acid bacteria species occupy different artisanal kefirs. The genus Gluconobacter is a member of the acetic acid bacteria family. Research has indicated a symbiotic relationship between LAB isolated from kefir and Gluconobacter spp. [34]. G. frateuii was identified in kefir originated from Belgium [31]. G. morbifer and Gluconobacter kondonii were identified in all artisanal kefirs examined in the presented work.

Kefir has been reported to be a health-promoting beverage. Numerous studies have suggested kefir's health benefits in terms of improving lactose digestion [35], protecting against foodborne pathogens, anticancer effects [36], immunomodulatory effects [37], and probiotic activity [5]. These health benefits appear to be related to the kefir microbiota and/or their metabolites [5].

Potential probiotics need to exhibit functional properties such as viability and persistence in the GI-tract, immunomodulation, antagonistic and antimutagenic properties [38]. The antagonistic abilities of probiotics include aggregation and coaggregation, adhesion to the intestine, inhibiting pathogenic bacterial adhesion to the intestine as well as production of antimicrobial substances such as bacteriocins [39]. Occurrence of LAB with probiotic potential in kefir has been reported. L. acidophilus LA15, Lactobacillus plantarum (Lactiplantibacillus plantarum) and L. kefiri (Lentilactobacillus kefiri) D17 isolated from Tibetan kefir were proposed as beneficial probiotics [17]. L. rhamnosus (Lacticaseibacillus rhamnosus) is reported to be a probiotic organism found in kefir [40]. L. paracasei (Lacticaseibacillus paracasei) MRS59 displayed significant antioxidant activity and adhesion to Caco-2 cells, which indicated its probiotic potential [41]. L. kefiranofaciens 8U, Lactobacillus diolivorans (Lentilactobacillus diolivorans) 1Z, and L. casei (Lacticaseibacillus casei) 17U isolated from Brazilian kefir were reported as potential probiotics [5]. Moreover, 11 Lac. lactis strains isolated from Brazilian kefir were reported to show probiotic properties such as antagonistic activity and antioxidative activity [41]. L. acidophilus Z1L, L. helveticus Z5L, and L. casei (Lacticaseibacillus casei) Z7L, isolated from Turkish homemade kefirs, were reported to have probiotic activities [42]. L. helveticus was identified in all artisanal kefirs in the presented work. Our results indicated that L. helveticus in kefir K product and kefir K grains was 5-84 times and 5-137 times more abundant than other artisanal kefirs and artisanal kefir grains, respectively. In this study, all bacteria found in kefir with known bacteriocin producing capabilities were reported to have beneficial properties, except L. apis. To our knowledge, L. apis has not been reported as a beneficial bacterium. L. plantarum Lp27, isolated from Tibetan kefir, exhibited efficient cholesterol-reducing ability [43]. L. plantarum was not found in any kefir grains or products in the current study.

The 16S rRNA gene sequencing described in the presented work has allowed us to determine LAB that might be responsible for the production of bacteriocins which were linked to the inhibition of foodborne pathogenic bacteria in our previously published study [19]. Lenti. kefiri is a bacterium that has 
been isolated from kefir and shown to inhibit both Gram (+) and Gram (-) pathogens [44,45]. Lenti. kefiri was the second most abundant lactobacilli in all artisanal kefirs except kefir K. In Taiwanese kefir grains, Lenti. kefiri was determined to be the most abundant Lactobacillus species [46,47]. L. helveticus, a species known to produce bacteriocins, was found to be the most abundant lactobacilli in kefir $\mathrm{K}$. This bacterium was reported to produce heat-labile, large molecular mass ( $>30 \mathrm{kDa})$ peptides lysostaphin, enterolysin A, and helveticin J with antimicrobial activities [48,49]. L. acidophilus was reported to affect the membrane permeability and cell wall formation of its target organisms by producing acidocin $B$, entereocin $\mathrm{P}$, and reuterin 6 peptides $[50,51]$. L. crispatus was reported in both in vivo and clinical studies to have antimicrobial activity against bacterial vaginosis and uropathogenic Escherichia coli [52,53]. In the presented work, L. crispatus was found to be 5.7-49 times and 5.7-65 times more abundant in KP and KG, respectively, when compared to other artisanal kefir products and their grains. Leu. mesenteroides was found in kefirs $\mathrm{K}$ and $\mathrm{C}$ in our work. The organism was reported to produce Leucocyclicin $Q$, a novel cyclic bacteriocin which shows antimicrobial activity against Gram-positive bacteria such as Bacillus coagulans [54]. Lacti. casei, which was found only in kefir L in the presented work, was reported to be effective against Lis. monocytogenes, Listeria innocua, Corynebacterium difterium, and Bacillus cereus. Lacti. rhamnosus was found in small abundance in kefir C, I, and L in our work. This organism was reported to inhibit Staphylococcus aureus, Lis. monocytogenes, Lis. innocua, C. diphtheriae, and B. cereus [55].

A research project that focused on the microbial diversity of Tibetan kefir grains from different origins did not detect Lac. lactis in kefir grains examined but in kefir products [56,57]. Another published study found that Lac. lactis and S. thermophilus were dominant microorganisms accounting for 53-65\% of the total microflora of Tibetan kefir grains and accounting for $74-86 \%$ of the total microflora of kefir products [58]. The artisanal kefirs tested in our work exhibit very low relative abundance for these organisms and thus they do not resemble the Tibetan kefir with dominant Lac. lactis and S. thermophilus. The variation in bacterial distribution in kefir products versus their grains can be attributed to temperature increase created by active fermentation or where these bacteria exist in the kefir grain [4] among other factors.

Owing to the fact that kefir A is a mixture of grains from various geographical regions, it is not surprising that it is related to kefir $\mathrm{K}$ and to all other kefirs in species level taxonomy. An interesting result for the species level taxonomy is that the Irish kefir is not closely related to the British kefir-even though Ireland is geographically close to Britain-but it is related to the Caucuses kefir. The British kefir is found to be closely related to the Lithuanian kefir. Kefir K, on the other hand, appears to be the most unique kefir in terms of its species-level taxonomy and its composition comprised of LAB reported to produce bacteriocins. In our former work [19], kefir K exhibited antimicrobial activity against a diverse group of foodborne pathogenic indicators. Due to kefir K's robust antimicrobial activity and its unique species-level taxonomy, our goal is to carry out additional research on kefir K with emphasis on isolation and characterization of LAB and their bacteriocins as well as application of these bacteriocins as natural, clean-label biopreservatives for shelf life protection and assurance of microbial food safety.

\section{Conclusions}

Geographical origins of kefir grains and kefir production methods affect the microbial composition of artisanal kefirs. Types of milk, incubation temperatures, incubation times, and the ratios of kefir grains to milk play important roles on kefir's microbial composition $[1,59,60]$. Kefir grains have been shown to exhibit regional differences in microbial composition due in part to local LAB finding a niche in the grains [6]. The culture-independent method employed in our work, the 16S rRNA gene sequencing, successfully revealed the microbial populations in six international artisanal kefirs and demonstrated the diversity and abundance of LAB found in each kefir tested, many with reported capability of producing bacteriocins and potential health benefits. Species found in high relative abundance in most artisanal kefirs included L. kefiranofaciens, Lenti. kefiri, L. ultunensis, L. apis, L. gigeriorum, G. morbifer, 
A. orleanensis, A. pasteurianus, Acid. aluminiidurans, and L. helveticus. LAB with documented bacteriocin production capabilities, Strep. thermophilus, Lenti. kefiri, L. helveticus, L. delbrueckii, Lacti. paracasei, Lacti. casei, Lacti. rhamnosus, L. crispatus, Leu. mesenteroides, L. acidophilus, and Lac. lactis, were found in diverse relative abundances in the artisanal kefirs examined in this study. LAB species with documented health benefits in the literature and identified in the artisanal kefirs tested in this work were Lent. kefiri, L. helveticus, L. delbrueckii, Lacti. paracasei, Lacti. casei, Lacti. rhamnosus, L.crispatus, L. acidophilus, S. thermophilus, Leu. mesenteroides, and Lac. lactis.

Supplementary Materials: The following are available online at http://www.mdpi.com/2076-2607/8/9/1318/s1, Figure S1 illustrates relative abundances of bacterial phyla and an aggregation of the 21 most abundant bacterial genera for the V1-V3 and V3-V4 regions of the 16S rRNA genes in four commercial kefir controls.

Author Contributions: Conceptualization, G.Ü.; methodology, A.S., M.B.B., and G.Ü; formal analysis, A.S., M.B.B., and G.Ü; investigation, A.S., M.B.B., and G.Ü; resources, A.S., M.B.B., and G.Ü; writing—original draft preparation, A.S. and M.B.B.; writing—review and editing, A.S., M.B.B., and G.Ü; supervision, G.Ü; project administration, G.Ü.; funding acquisition, A.S. and G.Ü. All authors have read and agreed to the published version of the manuscript.

Funding: This research was funded by the United States Department of Agriculture (USDA) National Institute of Food and Agriculture (NIFA) Hatch project [1015890)] and the BUILD Dairy Program of Utah State University (17597). The APC was funded by the BUILD Dairy Program of Utah State University (17597).

Acknowledgments: We thank Saudi Arabian Cultural Mission for their support of Abrar Sindi. We express our appreciation to Mete Yüksel for his assistance with the figures.

Conflicts of Interest: The authors declare no conflict of interest. The funders had no role in the design of the study; in the collection, analyses, or interpretation of data; in the writing of the manuscript; or in the decision to publish the results.

\section{References}

1. Nejati, F.; Junne, S.; Neubauer, P. A Big World in Small Grain: A Review of Natural Milk Kefir Starters. Microorganisms 2020, 8, 192. [CrossRef]

2. Nalbantoglu, U.; Cakar, A.; Dogan, H.; Abaci, N.; Ustek, D.; Sayood, K.; Can, H. Metagenomic analysis of the microbial community in kefir grains. Food Microbiol. 2014, 41, 42-51. [CrossRef]

3. Prado, M.R.; Blandón, L.M.; Vandenberghe, L.P.; Rodrigues, C.; Castro, G.R.; Thomaz-Soccol, V.; Soccol, C.R. Milk kefir: Composition, microbial cultures, biological activities, and related products. Front. Microbiol. 2015, 6, 1177. [CrossRef]

4. Bourrie, B.C.; Willing, B.P.; Cotter, P.D. The Microbiota and Health Promoting Characteristics of the Fermented Beverage Kefir. Front. Microbiol. 2016, 7, 647. [CrossRef]

5. Zanirati, D.F.; Abatemarco, M., Jr; Sandes, S.H.C.; Nicoli, J.R.; Nunes, Á.C.; Neumann, E. Selection of lactic acid bacteria from Brazilian kefir grains for potential use as starter or probiotic cultures. Anaerobe 2015, 32, 70-76. [CrossRef] [PubMed]

6. Nielsen, B.; Gurakan, G.C.; Unlu, G. Kefir: A multifaceted fermented dairy product. Probiotics Antimicrob. Proteins 2014, 6, 123-135. [CrossRef] [PubMed]

7. Delfederico, L.; Hollmann, A.; Martínez, M.; Iglesias, N.G.; De Antoni, G.; Semorile, L. Molecular identification and typing of lactobacilli isolated from kefir grains. J. Dairy Res. 2006, 73, 20-27. [CrossRef] [PubMed]

8. Neve, H.; Heller, K.J. The microflora of water kefir: A glance by scanning electron microscopy. Milchwirtschaftliche Forschungsberichte 2002, 54, 337-349.

9. Dobson, A.; O'Sullivan, O.; Cotter, P.D.; Ross, P.; Hill, C. High-throughput sequence-based analysis of the bacterial composition of kefir and an associated kefir grain. FEMS Microbiol. Lett. 2011, 320, 56-62. [CrossRef]

10. Gulitz, A.; Stadie, J.; Wenning, M.; Ehrmann, M.A.; Vogel, R.F. The microbial diversity of water kefir. Int. J. Food Microbiol. 2011, 151, 284-288. [CrossRef]

11. Montville, T.J.; Matthews, K.R.; Kniel, K.E. Food Microbiology an Introduction, 3rd ed.; ASM Press: Washington, DC, USA, 2012.

12. da C. P. Miguel, M.G.; Cardoso, P.G.; Magalhães, K.T. Profile of microbial communities present in tibico (sugary kefir) grains from different Brazilian States. World J. Microbiol. Biotechnol. 2011, 27, 1875-1884. [CrossRef] 
13. FAO/WHO. Evaluation of Health and Nutritional Properties of Powder Milk and Live Lactic Acid Bacteria; FAO/WHO: Córdoba, Argentina, 2001; pp. 1-4.

14. Hill, C.; Guarner, F.; Reid, G.; Gibson, G.R.; Merenstein, D.J.; Pot, B.; Morelli, L.; Berni Canani, R.; Flint, H.J.; Salminen, S.; et al. Expert consensus document. The International Scientific Association for Probiotics and Prebiotics consensus statement on the scope and appropriate use of the term probiotic. Nat. Rev. Gastroenterol. Hepatol. 2014, 11, 506-514. [CrossRef] [PubMed]

15. Yamane, T.; Sakamoto, T.; Nakagaki, T.; Nakano, Y. Lactic Acid Bacteria from Kefir Increase Cytotoxicity of Natural Killer Cells to Tumor Cells. Foods 2018, 7, 48. [CrossRef] [PubMed]

16. Xing, Z.; Tang, W.; Geng, W.; Zheng, Y.; Wang, Y. In vitro and in vivo evaluation of the probiotic attributes of Lactobacillus kefiranofaciens XL10 isolated from Tibetan kefir grain. Appl. Microbiol. Biotechnol. 2017, 101, 2467-2477. [CrossRef] [PubMed]

17. Zheng, Y.; Lu, Y.; Wang, J.; Yang, L.; Pan, C.; Huang, Y. Probiotic properties of Lactobacillus strains isolated from Tibetan kefir grains. PLoS ONE 2013, 8, e69868. [CrossRef] [PubMed]

18. Slattery, C.; Cotter, P.D.; O'Toole, P.W. Analysis of Health Benefits Conferred by Lactobacillus Species from Kefir. Nutrients 2019, 11, 1252. [CrossRef]

19. Sindi, A.; Badsha, M.B.; Nielsen, B.; Ünlü, G. Antimicrobial Activity of Six International Artisanal Kefirs Against Bacillus cereus, Listeria monocytogenes, Salmonella enterica serovar Enteritidis, and Staphylococcus aureus. Microorganisms 2020, 8, 849. [CrossRef]

20. Kim, D.H.; Jeong, D.; Kim, H.; Kang, I.B.; Chon, J.W.; Song, K.Y.; Seo, K.H. Antimicrobial Activity of Kefir against Various Food Pathogens and Spoilage Bacteria. Korean J. Food Sci. Anim. Resour. 2016, 36, 787-790. [CrossRef]

21. Balcázar, J.L.; de Blas, I.; Ruiz-Zarzuela, I.; Vendrell, D.; Gironés, O.; Muzquiz, J.L. Sequencing of variable regions of the 16S rRNA gene for identification of lactic acid bacteria isolated from the intestinal microbiota of healthy salmonids. Comp. Immunol. Microbiol. Infect. Dis. 2007, 30, 111-118. [CrossRef]

22. Gulitz, A.; Stadie, J.; Ehrmann, M.A.; Ludwig, W.; Vogel, R.F. Comparative phylobiomic analysis of the bacterial community of water kefir by 16S rRNA gene amplicon sequencing and ARDRA analysis. J. Appl. Microbiol. 2013, 114, 1082-1091. [CrossRef]

23. Zheng, J.; Wittouck, S.; Salvetti, E.; Franz, C.; Harris, H.M.B.; Mattarelli, P.; O’Toole, P.W.; Pot, B.; Vandamme, P.; Walter, J.; et al. A taxonomic note on the genus Lactobacillus: Description of 23 novel genera, emended description of the genus Lactobacillus Beijerinck 1901, and union of Lactobacillaceae and Leuconostocaceae. Int. J. Syst. Evol Microbiol. 2020, 70, 2782-2858. [CrossRef] [PubMed]

24. Marsh, A.J.; O'Sullivan, O.; Hill, C.; Ross, R.P.; Cotter, P.D. Sequence-based analysis of the microbial composition of water kefir from multiple sources. FEMS Microbiol. Lett. 2013, 348, 79-85. [CrossRef] [PubMed]

25. Wang, X.; Xiao, J.; Jia, Y.; Pan, Y.; Wang, Y. Lactobacillus kefiranofaciens, the sole dominant and stable bacterial species, exhibits distinct morphotypes upon colonization in Tibetan kefir grains. Heliyon 2018, 4, e00649. [CrossRef]

26. Chen, Y.P.; Hsiao, P.J.; Hong, W.S.; Dai, T.Y.; Chen, M.J. Lactobacillus kefiranofaciens M1 isolated from milk kefir grains ameliorates experimental colitis in vitro and in vivo. J. Dairy Sci. 2012, 95, 63-74. [CrossRef]

27. Hong, W.-S.; Chen, H.-C.; Chen, Y.-P.; Chen, M.-J. Effects of kefir supernatant and lactic acid bacteria isolated from kefir grain on cytokine production by macrophage. Int. Dairy J. 2009, 19, 244-251. [CrossRef]

28. Dertli, E.; Çon, A.H. Microbial diversity of traditional kefir grains and their role on kefir aroma. LWT Food Sci. Technol. 2017, 85, 151-157. [CrossRef]

29. Sylvie, C.; Marie-Laure, G.; Laurence, M.; Catherine, G.; Christiane, B.; Dominique, C.; Chantal, B. Lactobacillus gigeriorum sp. nov., isolated from chicken crop. Int. J. Syst. Evol. Microbiol. 2012, 62, 330-334.

30. Kimoto, K.I.; Aizawa, T.; Urai, M.; Bao Ve, N.; Suzuki, K.I.; Nakajima, M.; Sunairi, M. Acidocella aluminiidurans sp. nov., an aluminium-tolerant bacterium isolated from Panicum repens grown in a highly acidic swamp in actual acid sulfate soil area of Vietnam. Int. J. Syst. Evol. Microbiol. 2010, 60 (Pt 4), 764-768. [CrossRef]

31. Korsak, N.; Taminiau, B.; Leclercq, M.; Nezer, C.; Crevecoeur, S.; Ferauche, C.; Detry, E.; Delcenserie, V.; Daube, G. Short communication: Evaluation of the microbiota of kefir samples using metagenetic analysis targeting the 16S and 26S ribosomal DNA fragments. J. Dairy Sci. 2015, 98, 3684-3689. [CrossRef]

32. Özdemir, N.; Kök Taş, T.; Guzel-Seydim, Z. Effect of Gluconacetobacter spp. on Kefir Grains and Kefir Quality. Food Sci. Biotechnol. 2015, 24, 99-1116. [CrossRef] 
33. Garofalo, C.; Osimani, A.; Milanović, V.; Aquilanti, L.; De Filippis, F.; Stellato, G.; Di Mauro, S.; Turchetti, B.; Buzzini, P.; Ercolini, D.; et al. Bacteria and yeast microbiota in milk kefir grains from different Italian regions. Food Microbiol. 2015, 49, 123-133. [CrossRef] [PubMed]

34. Yang, Z.; Zhou, F.; Ji, B.; Li, B.; Luo, Y.; Yang, L.; Li, T. Symbiosis between microorganisms from kombucha and kefir: Potential significance to the enhancement of kombucha function. Appl. Biochem. Biotechnol. 2010, 160, 446-455. [CrossRef] [PubMed]

35. Hertzler, S.R.; Clancy, S.M. Kefir improves lactose digestion and tolerance in adults with lactose maldigestion. J. Am. Diet. Assoc. 2003, 103, 582-587. [CrossRef] [PubMed]

36. Ts, L.; MaryPramela, P.; Iyer, P. Anti-microbial, anti-fungal and anti-carcinogenic properties of coconut milk kefir. Int. J. Home Sci. 2017, 3, 365-369.

37. Güven, A.; Güven, A.; Gülmez, M. The effect of kefir on the activities of GSH-Px, GST, CAT, GSH and LPO levels in carbon tetrachloride-induced mice tissues. J. Vet. Med. B Infect. Dis. Vet. Public Health 2003, 50, 412-416. [CrossRef]

38. Saarela, M.; Mogensen, G.; Fondén, R.; Mättö, J.; Mattila-Sandholm, T. Probiotic bacteria: Safety, functional and technological properties. J. Biotechnol. 2000, 84, 197-215. [CrossRef]

39. Choi, A.-R.; Patra, J.K.; Kim, W.J.; Kang, S.-S. Antagonistic Activities and Probiotic Potential of Lactic Acid Bacteria Derived From a Plant-Based Fermented Food. Front. Microbiol. 2018, 9, 1963. [CrossRef]

40. Lim, P.L.; Toh, M.; Liu, S.Q. Saccharomyces cerevisiae EC-1118 enhances the survivability of probiotic Lactobacillus rhamnosus HN001 in an acidic environment. Appl. Microbiol. Biotechnol. 2015, 99, 6803-6811. [CrossRef]

41. Leite, A.M.; Miguel, M.A.; Peixoto, R.S.; Ruas-Madiedo, P.; Paschoalin, V.M.; Mayo, B.; Delgado, S. Probiotic potential of selected lactic acid bacteria strains isolated from Brazilian kefir grains. J. Dairy Sci. 2015, 98, 3622-3632. [CrossRef]

42. Sabir, F.; Beyatli, Y.; Cokmus, C.; Onal-Darilmaz, D. Assessment of potential probiotic properties of Lactobacillus spp., Lactococcus spp., and Pediococcus spp. strains isolated from kefir. J. Food Sci. 2010, 75, M568-M573. [CrossRef]

43. Huang, Y.; Wu, F.; Wang, X.; Sui, Y.; Yang, L.; Wang, J. Characterization of Lactobacillus plantarum Lp27 isolated from Tibetan kefir grains: A potential probiotic bacterium with cholesterol-lowering effects. J. Dairy Sci. 2013, 96, 2816-2825. [CrossRef] [PubMed]

44. Carasi, P.; Diaz, M.; Racedo, S.M.; De Antoni, G.; Urdaci, M.C.; Serradell Mde, L. Safety characterization and antimicrobial properties of kefir-isolated Lactobacillus kefiri. Biomed. Res. Int. 2014, 2014, 208974. [CrossRef] [PubMed]

45. Bosch, A.; Golowczyc, M.A.; Abraham, A.G.; Garrote, G.L.; De Antoni, G.L.; Yantorno, O. Rapid discrimination of lactobacilli isolated from kefir grains by FT-IR spectroscopy. Int. J. Food Microbiol. 2006, 111, 280-287. [CrossRef] [PubMed]

46. Chen, H.C.; Wang, S.Y.; Chen, M.J. Microbiological study of lactic acid bacteria in kefir grains by culture-dependent and culture-independent methods. Food Microbiol. 2008, 25, 492-501. [CrossRef]

47. Gao, X.; Li, B. Chemical and microbiological characteristics of kefir grains and their fermented dairy products: A review. Cogent Food Agric. 2016, 2, 1272152. [CrossRef]

48. Parada, J.L.; Caron, C.R.; Medeiros, A.B.P.; Soccol, C.R. Bacteriocins from lactic acid bacteria: Purification, properties and use as biopreservatives. Braz. Arch. Biol. Technol. 2007, 50, 521-542. [CrossRef]

49. Mahrous, H.; Mohamed, A.; El-Mongy, M.A.; El-Batal, A.I.; Hamza, H.A. Study bacteriocin production and optimization using new isolates of Lactobacillus spp. isolated from some dairy products under different culture conditions. Food Nutr. Sci. 2013, 4, 342-356. [CrossRef]

50. Suskovic, J.; Kos, B.; Beganovic, J.; Pavunc, A.L.; Habjanic, K.; Matosic, S. Antimicobial activity- the most important property of probiotic and starter lactic acid bacteria. Food Technol. Biotechnol. 2010, 48, $296-307$.

51. Mokoena, M.P. Lactic Acid Bacteria and Their Bacteriocins: Classification, Biosynthesis and Applications against Uropathogens: A Mini-Review. Molecules 2017, 22, 1255. [CrossRef]

52. Bulgasem, B.Y.; Hassan, Z.; Abdalsadiq, N.K.A.; Yusoff, W.M.W.; Musa, E.M.M.T.; Lani, M.N. Anti-adhesion activity of lactic acid bacteria supernatant against human pathogenic Candida species biofilm. Health Sci. J. 2015, 9, 1-9.

53. Griffin, C. Probiotics in obstetrics and gynaecology. Obst. Gynaecol. 2015, 55, 201-209. [CrossRef] [PubMed] 
54. Masuda, Y.; Ono, H.; Kitagawa, H.; Ito, H.; Mu, F.; Sawa, N.; Zendo, T.; Sonomoto, K. Identification and characterization of leucocyclicin Q, a novel cyclic bacteriocin produced by Leuconostoc mesenteroides TK41401. Appl. Environ. Microbiol. 2011, 77, 8164-8170. [CrossRef] [PubMed]

55. Simova, E.; Beshkova, D.; Dimitrov, Z. Characterization and antimicrobial spectrum of bacteriocins produced by lactic acid bacteria isolated from traditional Bulgarian dairy products. J. Appl. Microbiol. 2009, 106, 692-701. [CrossRef] [PubMed]

56. Zhou, J.; Liu, X.; Jiang, H.; Dong, M. Analysis of the microflora in Tibetan kefir grains using denaturing gradient gel electrophoresis. Food Microbiol. 2009, 26, 770-775. [CrossRef]

57. Liu, B.F.; Fan, M.T.; Jin, D. Isolation of lactic acid bacteria from Tibetan kefir grains and study on its fermentation performance. J. Northwest. Sci. Technol. Univ. Agric. Forrest 2004, 32, 83-86.

58. Simova, E.; Beshkova, D.; Angelov, A.; Hristozova, T.; Frengova, G.; Spasov, Z. Lactic acid bacteria and yeasts in kefir grains and kefir made from them. J. Ind. Microbiol. Biotechnol. 2002, 28, 1-6. [CrossRef]

59. Barao, C.E.; Klososki, S.J.; Pinheiro, K.H.; Marcolino, V.; Valarini, J.O.; Cruz, A.G.; Da Silva, T.T.; Tatiana, P. Growth Kinetics of Kefir Biomass: Influence of the Incubation Temperature in Milk. Chem. Eng. Trans. 2019, 75, 499-504.

60. Gul, O.; Mortas, M.; Atalar, I.; Dervisoglu, M.; Kahyaoglu, T. Manufacture and characterization of kefir made from cow and buffalo milk, using kefir grain and starter culture. J. Dairy Sci. 2015, 98, 1517-1525. [CrossRef]

(C) 2020 by the authors. Licensee MDPI, Basel, Switzerland. This article is an open access article distributed under the terms and conditions of the Creative Commons Attribution (CC BY) license (http://creativecommons.org/licenses/by/4.0/). 